\title{
New Social Orders: Reconceptualising Family and Community in Utopian Fiction
}

\author{
Kerry Mallan, Clare Bradford, John Stephens
}

\begin{abstract}
The family is the cradle into which the future is born; it is the nursery in which the new social order is nourished and reared during its early and most plastic period.

(Sidney Goldstein, Marriage and Family Living, 1946) 1
\end{abstract}

When Goldstein conceived the metaphor of the American family as the cradle of the future he was writing at a specific historical moment, 'one to which the stresses of war, the uncertainties of the ensuing peace, and the emerging relationship between ideologies of the family and American national identity together lent an unparalleled ambiguity and anxiety about family life' (Levey 2001, p.125). Nearly 60 years on, the same conditions seem still to apply not only to the United States, but also to many other countries across the globe. The linking of family to the social well-being of a nation and its individual citizens is a familiar rhetoric employed by politicians, religious leaders, social commentators, and scholars, who rely on the interplay between an actual social unit and its metaphorical extensions to produce an illusion of 'the truth'. In a similar way, the notion of a 'new social order' offers the utopian promise of a better life than that which current or past social orders have provided. Again the force of the metaphor resides in its capacity to appeal to both the intellect and the emotions.

Anew social order conjures a social imaginary, an idea first promoted in the late 1960s (see Castoriadis 1987), whereby a people can imagine and act as world-making collective agents. This new world possibility with its new social, moral, and political orders was given a fresh lease of life by the cataclysmic events of 1989 and their aftermath. With the end of the Cold War and the breakdown of the Soviet Union, a radically different intellectual and political world appeared possible. In the Soviet Union and its satellite states in Eastern Europe, totalitarian regimes were collapsing and the idea of a global civil society seemed to offer an alternative to the usual Cold War anticommunist rhetoric (Gaonkar 2002, p.2). However, the new millennium has seen this early optimism undercut by the rise of a new world disorder characterised by global terror, ethnic warfare and militarism. This sense of disorder is both real and unreal, depending on location. Many children living in countries such as Australia are spectators to televised accounts of war and social upheaval. For many other children, the ongoing dramas of violence, poverty, dislocation, and family destruction are part of their daily realities. The utopian promise of a new social order needs to take into account that 'Each society is created differently, subsists differently, and transforms itself differently' (Gaonkar 2002 , p.7). Therefore, the hope of a 'new world order' incorporating a universal acceptance of a Western-styled social, moral, and political order is not only a pipedream, but a dangerous one.

Against this backdrop of global politics and history, our discussion takes as its focus family and community as they are represented in seven utopian/dystopian fictions written for children and young adults and published between 1997 and 2004 by Australian, American, Canadian, and British writers. Because ideas about family structures can be used to model forms of cultural hegemony, we consider the tenuous and changing nature of 'family' as a social and political construct as it is both represented in the novels and promoted as a contemporary societal reality. The selected novels offer telling reflections of how various notions of new social orders have impacted on children's literature since 1990, and how this affects the utopian/dystopian strain which has long been present in children's literature. Because 'New World Order' is seldom articulated as an overt theme in children's literature, we are principally concerned with identifying versions of a mentality, a cast of thought, which might seem to be a product of the post Cold War era, or to be nuanced in a particular way attributable to the ideas and ideologies of that era. We therefore look for some kind of homology, a shape which bodies forth how the concepts and structures of a piece of writing might be mapped on to concepts and structures of the contemporary world. 2 This necessary obliqueness of attention entails that analysis will be fairly speculative, as we proceed from what does seem evident to what is arguably immanent.

We approach our topic initially by offering a brief sketch of current political discourse surrounding the ideology of family as the cornerstone of Western society. We then consider notions of family as they are developed in the selected texts and as they are articulated with other major issues, ultimately producing these issues as primary themes: 
assumptions about individualism in risk societies, including the role of creative and gifted individuals; the debate over cultural pluralism and multiculturalism; global concerns around refugee populations; and a revived, or perhaps continued, rhetoric about totalitarian nation states and the need to remove them. In our selected fictions, with the exception of Melvin Burgess's Bloodtide, various social imaginaries unfold, each gesturing towards a utopian outcome in which family becomes the unifying point for previously isolated or marginalised individuals. Bloodtide's dystopian future takes an extreme view of a number of family dynamics reflective of contemporary Western neoliberalism in which individualism, uncertainty, and risk have weakened dominant notions of families forged by blood. In Lois Lowry's Gathering Blue and Messenger contrasting social orders and families are depicted in ways that valorise American liberal pluralism and demonise monolithic totalitarianism, but presage the possibility that a new world order might be imposed within the parameters of a narrowly circumscribed pluralism. Narratives where individuals invent communities and form makeshift families feature in refugee novels by Deborah Ellis, Morris Gleitzman, and Ben Mikaelsen where young refugee characters traverse alienating social spaces which call for reconceptualisations of family.

We propose that family life involves an emotionally-charged set of practices whereby individuals in the family unit learn to relate to each other in ways that signify varying forms of allegiance, commitment, or possibly estrangement. Narratives about families can be seen to organise how a social group is represented, especially its knowledge and attitudes, and thus obliquely monitor the more extended practices of that social group. This effect can be discerned permeating the fabric of the narrative discourse, as in the following sequence from about two-thirds of the way through Gathering Blue. In this scene, the first clandestine meeting amongst three talented children selected to be the bearers of their community's cultural traditions, the beginning of resistance to indoctrination is linked with an other-regardingness imaged by the family. As Thomas and Kira soothe the stress and anxiety experienced by Jo, the youngest of the three, Kira tucks her into bed, slipping into a maternal role as she does so:
Kira smoothed the blanket. "Good night, then." For a moment she sat there on the bed, feeling a vague memory of something else that should be done. Something from when she was a small tyke, like this, being put to bed.

She leaned down toward the little girl, intuitively. What was it that her mother had done when she was small? Kira put her lips on Jo's forehead. It was an unfamiliar gesture but felt right.

The little girl made a small contented sound with her own lips against Kira's face. "A little kissie," she whispered. "Like me mum."

(Lowry 2000, p.152)

This is a carefully wrought sequence, blending memory and deeply embedded custom. The 'vague memory' transforms into an intuition, so that Kira gives and receives a kiss, but has no name for this 'unfamiliar gesture' and 'small contented sound' until the small child names it for her. The gap created by the underwording is a key move here, as it effectively affirms that a cultural practice expressing care, nurturing and compassion exists at a more primal level than language. As the three children momentarily enact a scene homologous with the ideal nuclear family they also take the first step towards subverting the totalitarian system which has appropriated their artistic talents. Eventually, Kira will also discover that their common state as orphans has been induced by calculated state violence that has been instrumental in destroying the functioning, traditional families out of which their talents have been born. An image of a reinstated family, then, becomes homologous with a reformed political structure.

\section{Family as social, political, and economic construct}

It's a commonplace that a person's spatial, geographical and social horizons expand between the times of infancy and adulthood, moving out from domestic space to neighbourhood, community and school, and then to city, nation and foreign places. The persistent claim that family relationships are the nucleus of human civilization, and the common use of family metaphors within political discourses, imply that a child's movement along that trajectory from domestic space into a wider world might be represented or interpreted as a movement along a 
metonymic chain whereby each stage has its particular significance but is also to some degree homologous with the next, larger stage. In other words, family stands for community, school, nation, and so on. Forms of the family in novels such as Gathering Blue imbricate with forms of community and governance and hence are deeply embedded within a society's ideology. The process is clearly evident in Lowry's next novel, Messenger, in the role of that society's schoolteacher (aptly named 'Mentor'). His mode of pedagogy through empathy is both closely homologous with an ideal of family relationships and depicted as an ideal mode through which to acculturate pluralism. But as the community falls prey to doctrinaire totalitarianism, his daughter laments that Mentor has become driven by selfish desire and xenophobia, and has forgotten what is truly important: 'how we use [poetry and language] to remind ourselves of how our lives should be lived' (p. 82).

Invariably, both secular and religious discourses in most Western societies promote the family as the cornerstone of civilization. 3 And yet 'the family' has been a hotly contested issue over the past decade, perhaps most overtly and publicly in the USA, as these key moments illustrate:

- In 1996 Congress passed, and President Clinton signed, the Defense of Marriage Act. (That statute protects marriage under federal law as a union of a man and a woman, and declares that one state may not redefine marriage for other states)

- In 2001, the US census indicated that the percentage of Americans living in nuclear families had declined to below 25 percent of the population; that the age at which couples married, if they did, had risen by five years (women, from 20 to 25 ; men, from 22 to 27 ); that during the 1990s, the number of single-parent families grew five times faster than the number of married couples with children.

- In 2004, in his third State of the Union address George W Bush stated: 'A strong America must also value the institution of marriage. I believe we should respect individuals as we take a principled stand for one of the most fundamental, enduring institutions of our civilization'.
Despite new configurations of families and kinship brought about by the impact of diversity and change on traditional social institutions since the $1990 \mathrm{~s}$, families have also been the silent witnesses, victims and targets of global conflicts and changing political agendas. With the spread of neoliberalism in Western societies and the quest for global hegemony amongst major powers, families are continually caught up in a framework of tradition and risk. As Ulrich Beck (1992) has argued, the emergence of the so called 'risk society' is both a contributor to and a product of neoliberal economics. One feature of this risk is that traditional allegiances and practices are either abandoned or prone to breaking down. Furthermore, if we accept the perception that we have moved from a culture of dependency to an age of 'post-emotionalism', in which people are largely indifferent to the needs and welfare of others and committed primarily to their own personal concerns and well-being, then the issue of family with the associated notions of trust and reciprocity emerges as a key concern both in the literature and in society. This point is confirmed and contested in our discussion of the novels.

As the above account demonstrates, it is no longer possible to promote a single 'Ozzie and Harriet' kind of family as the norm.4 Rather, competing family cultures and formations reflect the transformations that have occurred across Western societies and other parts of the world due to a number of catalysts including changing gender relations and technological innovation. While the 'crisis of the patriarchal family' is not a universal experience, in many contexts changing gender dynamics have resulted in fundamental redefinitions of relationships between women, men and children. However, these changes in the family are but one expression of a larger set of changes as technological innovation is responsible for such realities as 'designer babies', 'clones', and 'virtual communities'. In our selected examples, the outcomes of new technologies in communications and biosciences dramatically extend the boundaries of family structure and new social orders that are currently considered possible or desirable. The following section takes up this theme in relation to four novels located in futuristic settings: Melvin Burgess's Bloodtide (1999), Garth Nix's Shade's Children (1997) and the second and third novels in Lois Lowry's loosely 
connected trilogy, The Giver(1993), Gathering Blue (2000) and Messenger (2004).

\section{Futuristic families, contemporary concerns}

Bloodtide and Shade's Children locate families within futuristic dystopian settings. Bloodtide is concerned with division and divisiveness: rival gang families (the Volsons and the Conors) run illegal commerce and vie for absolute control of a dystopian London that is set apart from the technologically-advanced world by a wasteland populated by halfmen who eat anything that comes within their reach; divisions between wealthy and impoverished are cruelly demarcated and practices such as hanging tortured bodies from rafters are carried out as a form of public entertainment; division occurs between ordinary mortals and the destiny that unfolds for them by the reawakening of the god Odin; divisiveness runs in families where the tale of the Oedipal son unfolds, and incest and infidelity are necessary means to divide and conquer. While Bloodtide's post-apocalyptic setting and social commentary on dehumanization, megalomaniac rulers, and commercial opportunism provide familiar touchstones with respect to current global politics, Shade's Children takes as its subject the vulnerability and resilience of children in a world which cares little for nurturing the young within a loving and secure family unit. In this future dystopia, children are removed from their families, and routinely murdered for technological purposes at the rate of 100 per day. Children up to the age of 14 years have tracers implanted in their wrists so that they are unable to escape the confines of the Dorms where they are held until they are used as raw materials for the biotechnical creatures who terrorise renegade groups such as those who come under the protection of Shade, a computer-housed personality in search of a body. While the overthrow of the Overlords is the main quest of the four young protagonists, each of whom has an extraordinary individual talent, it is their forging of a community of friendship and loyalty that becomes the ultimate achievement.

Both Bloodtide and Shade's Children involve narratives of social domination, fear, and exploitation which accord with Tom Moylan's outline of 'the dystopian imaginary'. According to Moylan, early dystopian literary works such as E.M. Forster's short story 'The Machine Stops' teach that 'it is the totalizing political-economic machinery of the hegemonic system (and not simply the state, party, corporation, religion, or other undemocratic power) that brings exploitation, terror, and misery to society' (2003, p.136). While both Burgess and Nix dispense with the state as the locus of social control, they relocate that power in the hegemonic masculine subject: Conor, the ruthless megalomaniac ganglord (Bloodtide), and Shade, the self-appointed messianic 'electronic reality' (p.80) father figure (Shade's Children). The heroic narrative of destiny and conquest underpins both stories and as such they can be read within a Freudian Oedipal narration with their accounts of 'fatherhood' and patriarchal succession as the only viable means for progression towards identity formation and the continuity of culture. In the Oedipal tale, the originary violence of culture is masculine, and social reproduction and subjectivity are achieved by a repetition that reenacts the trauma of that violence. Crucial to the line of succession from father to son is the repudiation of the mother, seen as inhibiting separation and subjectivity for her children, and as a dangerous woman who must be countered by a masterful man in what may be called heroic Oedipal resolution.

In Bloodtide, mothers are either dead (dying in childbirth as in the case of the mother of twins Siggy and Signy), or absent (we know nothing of Conor's mother, and Signy virtually abandons her son Vincent). When a mother substitute is needed as a nurturing presence, she appears in the form of an old and deformed Pig (half-human) with a compassionate heart and the incongruously sweet name of Melanie. Melanie revives and cares for Siggy after he is savaged by Melanie's former lover, a ferocious, immense Pig, a half-man, half-pig creature that has a voracious appetite for human flesh. While Siggy is the heir apparent to the Volson kingdom, it is his twin sister, Signy, who has the necessary desire and ruthless capacity for hegemonic rule. However, as a masculinist tale, the narrative denies her this fate and so she must contend by playing the Oedipal mother: she creates Styr, a clone of her own son (Vincent), who (she hopes) will destroy the 'father' (Conor) in order that mother and son will rule in his place. Signy's path is a torturous one. After she is forced to marry Conor as 
part of a treaty instigated by her father, she is crippled when Conor's men sever her hamstrings and is confined to a wheelchair in the watertower. After she rebuilds her strength and recovers her limbs by subjecting herself to a rebirthing process in the womb tanks, her plan to become a powerful leader is thwarted when she is murdered by Styr. Consequently, the process of repudiation and elimination of the maternal and the dangerous feminine in the story leaves open the way for a heroic repetition of the authorising myth of patriarchy.

However, despite these narrative moves to erase the mother or the dangerous woman, Bloodtide attempts to have it both ways by denying the scheming and callous Conor his goal to be the leader of a new united London. Instead, Signy's twin brother, Siggy, emerges as a revisionist heroic figure: one who is disillusioned with combat and might find more peaceful ways to rule. He is also the chosen one of the god Odin. After the deaths of Conor and Signy, Siggy's reluctance to continue with the bloodshed is conveyed in the final words of the novel as Siggy gestures for his men to carry the dead body of his twin sister away from the fighting: 'He followed on, with no taste at all for the battle raging behind' (p.376). But his words lack conviction with respect to any hope of his becoming a revisionist leader, since he has repeatedly referred to himself in defeatist terms: 'I'm...no...hero' (p.293).

In Shade's Children, Nix's attempt to avoid the traditional heroic tale by using a female leader in Ella proves a flimsy ploy to distract from the masculinist tale that is at the heart of the narrative. Once Ella is killed, it is left to the besotted couple, Gold Eye and Ninde, to emerge from the climactic battle, destined to live the domestic fantasy of pre-Change times. When the Change occurred all people over the age of fourteen were removed from their families and homes, leaving only babies and children who were taken into the Dorms where they were educated to keep their brains developing and later sent to the Meat Factory where their brains were inserted into other biotechnical creatures known as Wingers. In an archival discussion session recorded as no. 24768, Gold Eye who was a survivor of the Change but escaped the Dorms, expresses his desire for home and family:

\author{
I like trees... grass ... only birds in sky. People \\ walking safe. Family. \\ No creatures. Sleep at night safe. Walk under the \\ sun in own place. \\ Grow plants. Build. \\ Be father with mother. Have children. A place like \\ Petar told me. Home.
}

After Change goes back...

I want home.

(Nix 1997, p.157).

Gold Eye's desire for home and family is realised in the final scene of the book when in some future time, he and Ninde are married and have two children whom they name after their dead friends Ella and Drum. The romance of the nuclear family that Gold Eye expressed as a boy of fourteen becomes his reality. In the final words of the story Ninde calls their children while unwittingly recalling the Oedipal return to the father: 'Ella! Drum! Daddy's here!'said Ninde. 'It's time to go home' (p.302). In this brief exchange, both identification and loss are acknowledged in a mini-narrative that plots the beginning of a family's history.

Not only does Nix ensure that Ella does not become the hero who lives to tell the tale, but his treatment of a powerful female leader, the Overlord Silver Star, supports the theme that is part of the Oedipal resolution: that of the dangerous woman who needs to be overthrown. Gold Eye's surprise on meeting Silver Star has more to do with the fact that the Overlord is a woman, than that she is a human and not a creature. While there is no chance of redemption for Silver Star, who 'was responsible for destroying 98 percent of the human race, someone who now preyed upon captive children' (p.290), Shade is given a last chance to redeem himself, as he misquotes from Shakespeare's Julius Caesar: 'There comes a tide in the affairs of men, that if the flood... or something like that. There is still a chance, a very slight chance. Perhaps I can redeem myself after all...' (p.292). If we trace the connections between text and intertext, we can read these words as Shade's desire for a new world order, characterised by peace and prosperity, which he pursued at the expense of his children's death yet failed to achieve due to his single-minded quest for knowledge. It is tempting to explore the parallels between the downfall 
of Caesar and that of Shade. If the chain of succession is to be handed down to Gold Eye then it remains open as to whether he will build a successful republic, as was the case with Caesar's adopted son Octavian (Caesar Augustus). And if so, then is autocratic patriarchal rule the only viable way to successful leadership?

While we read the conclusions of these texts with a degree of scepticism with respect to the utopian possibilities of restored democracies, both narratives nevertheless attempt to reclaim what Cornel West has aptly described as hope in dark times. 5 The hope is, however, not found in a shift of power from state to individual, but in the failure of Fukuyama's (1992) prediction of the triumph of neoliberal discourse of individualism and technology. By employing a discourse that is principally concerned with legitimating the political and cultural control of individuals and groups through technological sciences such as robotics and cybernetics, the texts also foreground Beck's notion of risk as an endemic characteristic of post-industrial, posttraditional societies.

In Shade's Children, despite the sophistication and superior strengths of the various creatures that have been produced through the technological intercourse of science and culture, it is human subjects working as a united group who succeed in overcoming these creatures. Such acts of social relations, working towards a transformed human-based social order, are a form of social capital which, according to Bourdieu (1986), relies on group memberships or connections to improve individuals' economic standing in capitalist societies. A hallmark of social capital, according to Winter $(2000, p .5)$, is that it is a resource for collective action that comprises the norms and sanctions of trust and reciprocity that operate within social networks.

While families have traditionally been viewed as the idealised model of social capital, two possible scenarios are played out in Bloodtide and Shade's Children. One is that the allegiance to family can become so strong that it not only weakens ties of community, but trust and reciprocity are not extended beyond the bounds of the family. This is a characterising feature of the warring gangland families in Bloodtide where the Volsons and the Conors are unable to trust those outside the family, and yet ultimately trust within the families is also destroyed. The other scenario proposed by the conservative critic, Fukuyama (1999), is that if the ties within family are weakened then this could lead to an increase in social ties outside the family. In Shade's Children, there are no biological families left after the Change. Consequently, young people who have been rescued by the computer-generated Shade are euphemistically his children, but in reality they are a collection of young people brought together through circumstance rather than through blood. Together they work toward the defeat of the Overloads, and although they have been denied childhoods and the nurturing that families traditionally offer children, they nevertheless learn to love and care for one another. By extension, this book signifies an alternative to those theories of social capital being measured by the strength of relations between parents and children and open up the possibilities for considering alternative family structures and networks beyond (hetero)normative familial relations.

In the light of recent debates about gay marriages in the United States, Canada, and Spain, the matter of social capital takes a different turn when queer families and communities based on non-sexual as well as sexual ties become part of the broader social and economic discourse. Although Bloodtide signals in its title the paradox of the tidal ebb and flow of blood relations, it also entertains the possible triumph that chosen ties can achieve. When the halfman resistance group led by Dag Haggerman enlist Siggy as a joint leader, the shared goal to overthrow the Conors is given impetus. This new impure collective of hybrid animal and human creatures constitutes a queer alternative to the pure genetic breeding that characterises the dominant gangland families. Metaphorically, this queer community offers transformative spaces of belonging that cross racial, sexual, biological, gender, and geographical lines. Ironically, it is the breaking of trust in both novels that triggers the downfall of family unity and the rise of a new social order. When Signy tricks her twin brother into an incestuous act this is merely one of the many deceptions in which she engages. Notions of traditional family relations, maternal love, and matrimonial loyalty are queered by the birth of Siggy and Signy's child Vincent and the accelerated growth of his clone Styr. However, Signy's actions are 
motivated by her desire to avenge her husband's murder of her father and older brothers and her brutal crippling at the hands of his men, and afford a means for plotting the downfall of Conor. In a similar vein, Shade's betrayal of his children effects the downfall of his adoptive family enterprise. Consequently, both books canvas new forms of identity and belonging that emerge out of risk societies where original blood ties are severed but new productive allegiances are forged.

The closures of these novels embody a utopian impulseone that hopes for a better future. Given Beck's account of the aspects of social change that currently characterise risk societies, that of 'manufactured uncertainty' and 'increased individualisation' one wonders if the new social orders in the making in these narratives are culturally and strategically positioned to ensure the reproduction of more equitable social relations than we currently experience. The texts we now move to, Lowry's Gathering Blue and Messenger, also signal toward the formation of new social orders, but arguably fall short of advocating transformative changes to the patriarchal family structures which maintain their discursive power, even as they are replaced by other forms and configurations of family.

In the dystopian society depicted in Lowry's Gathering Blue, families are mostly associations which preclude love between men and women, and between parents and children. Parents kick and beat their children, drive them away, and even murder them. Thus when Kira, the principal character, is orphaned, the women of the village seek to take the site of her family home to build a pen in which to keep their children and chickens. Without a functioning family life, the society is incapable of any acts of altruism or compassion, a lack brought home to Kira when for the first time she meets Christopher, her blinded father, and hears the story of how, having been attacked and left for dead, he was nursed back to health by members of the utopian 'village of healing' - a place 'much quieter than this village. There is no arguing. People share what they have, and help each other. Babies rarely cry. Children are cherished' (Lowry 2000, pp.204-205).

The exceptions in Kira's village are the few families in which husband and wife are bound to each other by love, and raise children bound to them by biology. These are the families which produce children who become creative artists and who are capable of other-regarding behaviour. When the families are destroyed so that the village governors can harness the powers of the children for their own ends, the social role of the unique, creative individual is cast into sharp relief.

The 'village of healing' briefly described in Gathering Blue is the place simply known as 'Village' in Messenger. Here, family structures are of a different kind. They are traditional families or blended families constructed by putting together refugees who found their way to Village. The process is clearly metonymic of the American melting pot metaphor, whereby heterogeneous peoples blend together to make a unified, homogenised society. The ideology approximates to American liberal pluralism - an assumption that cultural, social and economic constraints can be refashioned in such a way as to realise relative equality, freedom and justice. 6 In cultural discourses, pluralism and diversity have long been contrasted with monolithic - totalitarian - regimes. This is where Lowry's trilogy is situated.

Gathering Blue depicts Kira's gradual discovery that the regime in which she lives is totalitarian, and controls its subjects by false propaganda about the supposed dangers that surround them and the benignity and wisdom of their rulers, by falsifying history, and by discreetly exterminating people who show signs of dissent. The model for this in American imagery would be, say, North Korea or Iran. As one of the three children - a tapestry maker, a woodcarver, and a singer - charged with the perpetuation of ideology, she grasps that through the efforts of creative individuals ideology can be undermined from within and refashioned along more pluralistic lines. Messenger depicts the near demise of a democratic and pluralist society through the advent of self-interest and a loss of altruism. This is represented in two forms. First, the forest surrounding Village thickens in a way heavy with symbolic suggestion, so that pathways disappear and anyone who ventures into the forest is likely to be ensnared and destroyed by the plants. The metaphorical significance of this process is explicated at the close of the novel: 'It was an illusion. It was a tangled knot of fears and deceits and dark struggles for power that had disguised itself and almost destroyed 
everything' (2004, p.168). More literally, the residents of Village, under the sway of racism and mob rule, determine to close their borders and build a wall to keep further refugees out. The arguments - the newcomers consume limited resources; they don't speak the same language; they bring disease; they increase crime - are familiar from numerous racist and anti-immigration campaigns throughout the world.

The opposition between a liberal pluralism and totalitarianism which is perhaps a central theme of these novels is evident in two ways. On the one hand, it is possible to point to specific passages which articulate such an ideology, and on the other, the outcomes produced by the overarching narrative structures appear to affirm this position on a more teleological scale. Specific articulations are found in passages such as these:

Kira knew, suddenly and with clarity, what it all meant. ... [The three of them] were the artists who could create the future....

The guardians with their stern faces hadno creative power. But they had strength and cunning, and they had found a way to steal and harness other people's powers for their own needs. They were forcing the children to describe the future they wanted, not the one that could be.

(Lowry, Gathering Blue 2000, pp.211-212. Our ellipses.)

[Matty knew] that there were communities everywhere, sprinkled across the vast landscape of the known world, in which people suffered. Not always from beatings and hunger, the way he had. But from ignorance. From not knowing. From being kept from knowledge.

(Lowry, Messenger 2004, p.25)

Matty could see and hear everything. ... He heard the new [refugees] singing in their own languages - a hundred different tongues, but they understood one another. He saw the scarred woman standing proudly in their midst beside her son, and the people of Village gathered to listen.

(Lowry, Messenger 2004, pp.167-68)
The ideologies evoked in these extracts - the liberating ideology of Kira and Matty, and the repressive ideologies they have learnt to recognise and oppose-resonate with post Cold War rhetoric. The principle of action of totalitarian regimes is to attempt to restrict the possibilities for meaning and hence to direct the movement of history. Against this principle stands creative pluralism ('a hundred different tongues'), the 'new' order for a post-totalitarian world. Kira's decision at the end of Gathering Blue to employ her art transformatively has clear teleological significance, in that it is the culmination of a process of understanding and maturation. Its rightness is confirmed in Messenger, when Matty arrives in the village and, observing that girls are now educated, remarks on the positive change that has taken place. Much more obviously, Matty's own heroic self-sacrifice to undo the thickening of the forest bodies forth the form taken by the global opposition to totalitarian regimes after the Cold War era. Throughout the Cold War, as the conservative social commentator Russell Jacoby (1999, p.44) points out, American society pitted the idea of pluralism (that is, its self-construction as a bundle of contending and diverse groups) against the spectre of totalitarianism. This is still the strategy Lowry offers in representing the positive strike against totalitarian regimes taken by enlightened, heroic individuals in favour of re-creating pluralist societies. 7

As with the other examples we have discussed, these are, effectively, political novels because the ideas that underpin them are central to contemporary politics. The potential of creative, visionary characters (Kira in Gathering Blue, and Matty, Seer and Leader in Messenger) to valorise pluralistic family and community structures points outwards to a larger political message in the context of key cultural and political debates in the post Cold War era. Pluralism and diversity may seem woolly concepts, and many people today fear the possibility that they may be readily appropriated in a process whereby monolithic cultural practices may become imposed upon more local cultures. On the other hand, pluralism may also be the best doctrine that our era has to advance to resist such cultural imposition.

It may be argued, however, that having raised these issues Lowry has largely evaded addressing them because here the social transformation that flows from the actions of 
the characters always takes place after the close of the particular novel. One consequence of this is that, despite their reformist agenda, none of the novels depicts, or even hints at, a change in governing structure away from benign patriarchy. Messenger, the most explicit of the novels that make up the pluralism-totalitarianism trilogy, comes closest to offering a utopian vision through its use of a loss and recuperation structure. That is, the daily life of Village depicted in the second chapter-'quiet and peaceful ... slow and cheerful', under the perceptive care of three wise men, Leader, Mentor and Seer-is threatened by false desires and destructive forms of individualism, but restored by Matty's sacrifice at the close. More locally, the close suggests confirmation of Matty's idea that Kira (protagonist of Gathering Blue) and Leader (protagonist of The Giver) would become a couple. First expressed by Matty in Gathering Blue, it is narratively reiterated just prior to Matty and Kira's journey to Village, when Kira's ability to produce and read visionary tapestries is used to foreshadow their journey:

"Forest is thickening. So we must hurry, Matty."

Odd. It was the same thing that Leader had seen.

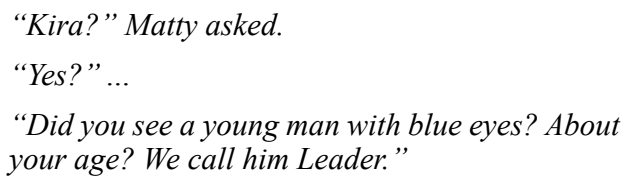

She stood still for a moment, thinking. A strand of dark hair fell across her face, and she brushed it back with her hand. Then she shook her head. "No," she said. "But I felt him."

(Lowry 2004, p.127)

That Kira and Leader share a common insight hints that they may indeed be destined to become a couple, joined by their wisdom and paranormal abilities. The implied bond involves more than that, however. The feminine gesture that lies between the question and Kira's answer draws sudden attention to her female embodiment, and gives a particularly feminine resonance to her intuitive (rather than visual) perception of Leader's presence in Village. The sequence foreshadows how the teleology of the novel, and of the trilogy, resolves into a traditional romance outcome, with the destined couple mourning over the body of their mutual friend and carrying it to Village for burial. Their anticipated union-foreshadowed by story direction, their roles as principal characters, and the almost clichéd final tableau - synthesize all of the themes we have been pointing to, as the sequence is resolved into a family bond which promotes cultural pluralism while celebrating the specialness of creative visionaries, and makes a victorious stand against the 'tangled knot of fears and deceits and dark struggles for power' which lead to totalitarian regimes and closed societies.

In the futuristic settings of the narratives we have so far discussed, contemporary debates and concerns about changing family structures and their relationships to social and political orders are necessarily approached obliquely - among other strategies, through analogies, metaphors, parallels and intertextual play. The refugee novels we now consider, Deborah Ellis's Parvana's Journey (2002), Ben Mikaelsen's Tree Girl (2004) and Morris Gleitzman's Boy Overboard(2002), are set in contemporary societies where war, inter-factional violence and privation destabilise family and community structures.

\section{Refugee narratives and substitute families}

In Deborah Ellis's Parvana's Journey, the protagonist, Parvana, lives in Afghanistan during the rule of the Taliban. Her father has died, and she travels alone, looking for her mother and two sisters from whom she has become separated. In a bombed village full of corpses she rescues a baby who lies next to his dead mother; when she and the baby, Hassan, shelter in a cave, she encounters a onelegged boy, Asif, who accompanies her and Hassan on their journey. She comes across eight-year-old Leila and her grandmother in the wreckage of their farmhouse, and the two girls engage in the following conversation:

\section{Leila smiled at Parvana.}

'Let's be sisters, 'she said.

Being sisters sounded fine to Parvana.

'All right. We'll be sisters.'

'Can your brothers be my brothers?'

'You mean Asif and Hassan? They're not my brothers. We just sort of found each other.' 


\section{'That makes them your brothers, 'Leila said. \\ 'Yes, I guess it does, 'Parvana agreed ... (Ellis 2002, p.115)}

Leila's conviction that 'just sort of finding each other' is a way of forging family, and Parvana's hesitation ('Yes, I guess it does'), point both to the fact that formulations of family need not depend on genetics, and also to the dominance of the nuclear family as the normative model. While the following texts involve displaced and fugitive children, we argue that the ideas about family structures, relationships and practices which they broach are broadly applicable as well to contemporary re-imaginings of family.

A point made at the beginning of this paper highlighted the fact that in the wars and conflicts of the late twentieth and early twenty-first century, the largest group of casualties is constituted not by military personnel but by women and children. As Neil Boothby says, '[L]arge percentages of children in countries afflicted by armed conflict are being exposed to violence, torture, hunger, loss of family, displacement from communities, and forced recruitment into military and paramilitary groups' (1996, p.150). As children's literature responds to this landscape of ethnic and religious violence and mass migration, a body of texts has emerged which can be termed 'refugee narratives' - fiction which foregrounds the identity-formation of child refugees. The implied readers of refugee narratives are not refugees but citizens of Western democracies, who cannot be expected to have more than a glancing knowledge of the geographies, histories and politics of the settings of these novels. Typically, the gap between protagonists and implied readers is mediated through narratives which seek to align readers with first-person narrators or focalising characters, and which provide cultural and historical information principally through dialogue between protagonists and other characters.

In Democracy Without Enemies (1998), Ulrich Beck distinguishes between two modernities: the first, shaped by industrial society and the nation-state and dominated by loyalties to family, ethnic group, class and so on. The second modernity, in which 'the identity structure of industrial society and the nation-state is losing its ontological cement' (1998,p.74), is characterised paradoxically both by globalising forces in the form of multinational conglomerates, and by the collapse of 'patterns of preordained affiliations' which structured human life during the 'first modernity' (1998, p.76). Beck then goes on to speculate on the advent of what he describes as a 'utopia of self-limitation' (1998, p.166), which reacts against the blind 'faith in progress' which marked the first modernity.

Beck's theory of self-limitation does not depend on a strong state, market forces, nostalgia or a retreat into neoconservatism. It lies, he says, in principles such as the following: 'Cheaper is more beautiful,... slower is more democratic, being more self-responsible is more fun' (1998, p.166). In his 2002 work Individualization, Beck reflects on how welfare reform, industrial change, cross-cultural relations and so on are reshaping the family within the 'second modernity': 'The family is becoming more of an elective relationship, an association of individual persons, who each bring to it their own interests, experiences and plans and who are each subjected to different controls, risks and constraints.... Since individualization also fosters a longing for the opposite world of intimacy, security and closeness, most people will continue...to live within a partnership or family' (2002, p.97). In place of the older hierarchies of gendered and generational power within families, the 'post-familial families' which Beck describes operate through negotiation and through 'a virtual exchange of roles, of listening and taking responsibility for one another' (1998, p.81). Beck's 'post-familial family' is homologous with the political structure he proposes, since he calls for federative ideas, for a dismantling of hierarchies and for a world in which 'the actors are forced into reflection on the distant effects of their actions' (1998, p.166).

The refugee novels we discuss involve children displaced from their homes and families and seeking better futures. Tree Girl is set in Guatemala during the 36-year civil war which ended in 1996; Parvana's Journey is set in Afghanistan; and Boy Overboard traces the progress of Jamal, an eleven-year-old boy, his sister Bibi and their parents, refugees from Afghanistan who seek asylum in Australia. Produced in the United States, Canada and Australia, these are openly activist texts in that they promote 
internationalist principles and political action. Two of the novels also interrogate neo-liberal national politics: in Tree Girl, the role of the United States in supporting military rule in Guatemala, and in Boy Overboard the brutal policies of the Australian government which require that asylumseekers be placed in mandatory detention.

In Tree Girl, Gabriela Flores, a fifteen-year-old Mayan girl, returns from selling coffee at market to discover that soldiers have massacred her entire village including her family except for her sister Alicia. In a sequence similar to that in Parvana's Journey, Gabriela delivers a baby born to a dying woman and with Alicia and the baby sets out on the long walk to a refugee camp in Mexico, but she is separated from the two younger children during a second massacre and continues on her way alone, though as part of a constant stream of refugees from Guatemala to Mexico. In Parvana's Journey, Parvana is alone in the north of Afghanistan after her father's death; and in Boy Overboard Jamal's parents pay a smuggler to take the family to Australia. Jamal and his sister Bibi are separated from their parents, whose boat sinks just outside Australian territorial waters. All three novels end in refugee camps where protagonists are reunited with family members; but crucial episodes in these narratives are built on events during which refugee children form new alliances of cooperation and support, principally, as Parvana says in the quotation with which we began, by 'just sort of finding each other'.

In Tree Girl and Parvana's Journey, generational hierarchies are disrupted as children take responsibility for dependent adults. The child Leila, who has survived for months in the ruin of her home by the time Parvana discovers her, has been caring for her mute and traumatised grandmother. In Tree Girl, Gabriela survives in the camp by scavenging and fighting for supplies. One day, when blankets and plastic tarpaulins are being distributed by aid workers, she fights with two old women and a young boy over a package, grabbing it from them and leaving them sprawled on the ground. Later, Gabriela sees the two women and feeling ashamed of her behaviour gives them the tarpaulin she has obtained, whereupon they decide that it is big enough for three people. Gabriela finds lengths of wood to hold it up, and they use it as a tent. In the interplay between Gabriela and the women, echoes of former hierarchies are re-enacted and reworked to embody new relationships based on interdependency. In the following passage, for instance, Carmen, one of the two women, gestures toward traditional practices where elders knew better than children:

'I'll try to find you food tonight,' I told [Rosa and Carmen] as they thanked me again and again for the shelter.

'Maybe it isn't safe for you to go out in the dark,' Carmen said.

'And maybe it isn't safe to starve to death,' I replied.

(Mikaelsen 2004, p.169)

Beck remarks of traditional relations between children and parents in Western societies that children are 'privately enslaved' by their parents in the guise of care, [and] coddled politically, legally and morally' (1998, p.76). Refugee narratives involve extreme situations where children are not only not coddled, but are subject to being killed, maimed, imprisoned and tortured. Even as they position readers to align their subjectivities with those constructed for refugee children, these narratives engage in distancing strategies which position readers as observers of otherness. In Parvana's Journey, for example, Parvana stays with a family in the village where her father dies. One night the eldest girl in the family wakes Parvana at night and warns her that the old men in the village intend to sell her to the Taliban (she dresses as a boy for safety) to become a soldier. The girl implores Parvana to take her as well, but Parvana refuses:

Parvana couldn't look at the girl's face. If she took the girl with her, all the men of the village would come after them. The girl would be in terrible trouble for dishonouring her family, and Parvana would be turned over to the Taliban.

(Ellis 2002, p.21)

As the narrative here lingers on the motivations of the old men - and the prospects of punishment for the girl and life as a boy soldier for Parvana - its explanatory mode distances its Western audience from events by pointing to the gap between Parvana's world and that of the novel's implied readers. This instance demonstrates the central problematic of refugee narratives: that they are implicated 
in differentials of power which privilege Western cultures. This is clear, for instance, when episodes of violence are so luridly represented that readers are positioned as voyeurs of suffering and objectified figures. Secondly, and flowing from the objectification of suffering others, is the propensity for stories of atrocities and cruelty 'over there' to enhance a sense of Western superiority.

Utopian moments in these narratives are to be found in the mundane, everyday negotiations through which protagonists produce themselves as other-regarding subjects. In Parvana's Journey, as the children form a makeshift family in Leila's home (a semi-ruined building surrounded by landmines) they take on the tasks to which they are most suited: the one-legged boy Asif, who is patient and determined, washes an infected sore on Leila's face; Leila and Parvana begin to make a garden; the three children pull Leila's grandmother outside on her mattress so that she will feel the sun. In the unposted letters Leila writes to her friend Shauzia, she describes their community as 'a real Green Valley,... a place that is happy and free' (p.117) where the war cannot enter. When the war does enter, in the form of a missile which destroys the house and kills Leila's grandmother, the children embark on a dangerous journey to a refugee camp; but the narrative sets the privations of this journey against the ideal of the children's brief period of purposeful and communitarian endeavour.

Beck envisages the 'post-familial family' as an elective arrangement involving 'a virtual exchange of roles, of listening and taking responsibility for one another' (1998, p.81), a description of inter-subjective relations which accurately describes the families formed by refugee children. In Boy Overboard and Parvana's Journey, protagonists encounter children whose personal histories render them reluctant to trust others. The cross-grained Asif, in Parvana's Journey, resists Parvana's overtures when she discovers him hiding in his cave. Later, when she decides to embark on a search for her mother and sisters, the following exchange occurs:

'It would probably really annoy you if I came with you, wouldn't it?' Asif said. 'You'd probably hate it. You're probably wishing and wishing that I'll stay behind.'

\author{
Parvana ... didn't say anything. \\ 'In that case, 'Asif said, 'I'll come. Just to annoy \\ you.'
}

Parvana felt a strange, surprising relief. She had known, deep down, that she wouldn't have been able to leave him behind.

(Ellis 2002, pp.73-4)

Parvana and Asif play out psychological games such as this over and over again. Because Parvana is the main focalising character, readers are privy to her struggles to comprehend Asif's behaviour, but it is not until Asif confides in eight-year-old Leila, later in the narrative, that his history is revealed - that he was orphaned as a young child, and beaten by his uncle until he ran away. The dynamics of these relationships are inflected but not determined by culturally-inflected hierarchies of gender and age (thus, Asif resents Parvana's decisiveness because she is a girl, even though older than he is). Crucially, the separate histories, interests and plans which each of the three brings to their relationships shape the substance and style of their negotiations. Without a common past or an imagined future, they must invent what Beck describes as 'the everyday details of do-it-yourself relationships' (p.98) which enable them to balance individual and group interests.

Just as the trajectory of Parvana and Asif's relationship progresses through mistakes and misunderstandings as well as moments of empathy, so a similar process obtains in Boy Overboard, in the relationship between the narrator Jamal and the boy Omar. The two boys first meet when Omar attempts to steal Jamal's soccer ball. Later, when Jamal and his sister Bibi are separated from their parents, they form an alliance of sorts with Omar and with a teenage girl, Rashida, who is an outcast by virtue of her Western-style clothing and make-up and her rebellious demeanour. Just as Parvana is unable to access Asif's motives, so Jamal is a naïve narrator who does not recognise what is obvious to readers - that Omar's behaviour is that of a shrewd and practised survivor. The reasons for this become clear toward the end of the novel, when Omar reveals that he is an orphan who has survived by attaching himself to large family groups who eventually incorporate him as a kind 
of fringe-dweller, and by deploying tactics such as theft, self-concealment and evasiveness.

The coalitions formed by refugee children involve individuals of different cultural, educational and ethnic backgrounds. In Tree Girl, Gabriela's alliance with the two old women Rosa and Carmen reaches across ethnic and language boundaries, since while all three belong to Indigenous groups descended from the Mayans, Gabriela is Quiche, and Rosa and Carmen are Kakchikel. Differences of class, caste and education are, however, more common in these narratives. The parents of the protagonists Parvana, Gabriela and Jamal hold enlightened and progressive views: Jamal's mother runs a school in her home despite Taliban prohibitions; Parvana's father was a British-educated history teacher who taught Parvana about 'the greatAfghan and Persian poets'(Ellis 2002,p.24); and Gabriela's parents encourage their daughter to attend school notwithstanding their poverty. In terms of story, such parental figures afford an explanation for the fact that the protagonists of these novels are resistant to dominant ideologies despite the fact that they come from subordinate social groups. Viewed in relation to the discourses which shape narratives, these admirable parents and children fit within paradigms familiar in fiction by Western authors - namely, where non-Western others are admirable because they are exceptional within their cultures, and hence more 'like us' than, for instance, Taliban supporters in Afghanistan or Spanish-speaking soldiers in Guatemala.

Given the above accounts of the utopian inflexions in constructions of elected families in refugee narratives, the discussion now considers what happens in these novels when protagonists are reunited with their genetic families. In Tree Girl, Gabriela's young sister Alicia reaches the camp together with Maria, a woman whose family was killed by soldiers, and who has cared for both Alicia and the baby delivered by Gabriela toward the beginning of the narrative. When Gabriela takes the three to Carmen (Rosa, the other old woman, has died), a renegotiation of roles and responsibilities is necessary, since, as Carmen reminds Gabriela, 'kindness can kill you in this place' (2004, p.186). Gabriela takes on duties as an assistant teacher and establishes a school in the camp with Mario, a resistance fighter who was formerly a teacher. When Mario leaves the camp to return to his troop, Gabriela resolves to leave also, with Alicia, telling herself that Alicia is after all her only 'real family' (p.214). However, as she walks out of the camp, children and adults address her with affection and regard, and she decides instead to remain and continue her work of teaching, so that the closure of the narrative folds into a promotion of communitarian values rather than the claims of family as a genetically-defined unit.

At the end of Parvana's Journey, Leila runs onto a minefield to pick up a relief package, and is fatally injured. Parvana gathers up the dying child, and when she brings her back to the barrier discovers her own mother, who unknown to her has been living in a distant part of the camp. At the novel's end Parvana lives in a blended family group with her mother and sisters and her elective brothers, Asif and the baby Hassan. In Boy Overboard, Jamal and Bibi are reunited with their parents and re-form their family group. Partly because these novels end in the marginal spaces of refugee camps, their reunited families seem oddly diminished compared with sequences during which refugee children are agential in forging relationships. To some extent, they echo those conventional trajectories where children first engage in adventures outside the controlling influence of parents and other adults and then return to the security of homes and families. In refugee narratives, however, the formation of elective families within intensely dystopian settings is associated with the possibility of better futures.

While these hopeful signs manifest in moments when children take responsibility for themselves and others within elective families, refugee narratives place little faith in larger political entities such as nation-states. In Boy Overboard, Jamal realises that the Australia which he has idealised as a welcoming, inclusive and soccer-playing society is so obsessed with border control that he and his family are incarcerated on a South Pacific island; in Tree Girl, Guatemala is ruled by militia who relentlessly persecute its Indigenous inhabitants; and in Parvana's Journey the nation is reduced to factionalised and fragmented groups under the Taliban. There is no scope here for a nationalist imagination, since the local and the national are at odds. The elective families formed by Parvana, Gabriela and Jamal, built on respect, mutuality and empathy, propose 
political and cultural processes radically different from those which have produced refugee populations.

\section{CONCLUSION}

As our discussion has noted, many of these novels offer hope in terms of better futures. For many Western young readers these books mediate between the fragmented and often frightening televised images of war, refugees, detention centres, and violence by offering tales that for the most part reassure readers that young people can take responsibility for themselves and others even in the most extreme circumstances. The corollary also applies to these stories of youthful agency as they also tell of young people who do not survive, who are harmed or killed as the result of conflict and oppression. As we have argued, dominant discourses, both secular and religious, inform conventional notions of the traditional family and kinship patterns. These discourses are generated in Western societies through various ideological and economic strategies by governments, religious institutions, and popular media. Within and against this overarching discursive framework, we might consider how the fictional texts discussed in this paper and others have the potential to open up wider consideration and discussion of family relationships and in so doing afford knowledge of, and insights into, the world within which we live. It is this rootedness in the present that marks utopian/dystopian literature's ability to engage with concerns of contemporary society through a hypothetical unfolding of some possibilities (both redemptive and apocalyptic) inherent in the present condition. The challenge we see in reading utopian novels that deal with families and difficult times is that we need to be sensitive to the atrocities they describe as well as assess the creative adaptation of their utopian refiguration. By exploring the cultural face of their new social order we can attend to how difference is refracted within both the familiar and the alternative social imaginaries they propose. If the family is the cradle of the future, then we need to be alert to the hand that rocks the cradle.

This essay is an outcome of a project funded by the Australian Research Council.

\section{NOTES}

1. See Jane F. Levey (2001) 'Imagining the family in postwar popular culture: The case of The Egg and I and Cheaper by the Dozen', Journal of Women's History 13,3, p.125.

2. Homology refers to parallels, correspondences, or likenesses in structure or in position within a system. Thus two different structures, such as family and school, may follow a similar pattern-e.g., a comparable hierarchical structure - or contain similar elements.

3. See, for example, Jan Lundberg, 'U.S. civilization's weakness evident in family trends', Culture Change, http://www.culturechange.org/e-letter-15cont.html (accessed 7 August 2005).

4. After the 2001 census in the USA, the online journal Salon.com posted an analysis which began by declaring that potent icons of the nuclear family, such as 'Ozzie and Harriet' are 'faded and fictional, not to mention completely overwhelmed by general cultural consensus and demographic studies'. Amy Benfer, 'The nuclear family takes a hit,'Salon.com, June 7, $2001 \mathrm{http}: / /$ www. salon.com/mwt/feature/2001/06/07/family_values/

5. See Ellis, Katie (2003) 'Cornel West talk draws turnaway crowd', Inside BU, March 6. 24, 22 (accessed June 5, 2005).

6. SeePeter McLaren (1994) 'White terror and oppositional agency,' in David Theo Goldberg (ed.) Multiculturalism: A Critical Reader. Oxford, Blackwell, p.51.

7. The pattern is established in The Giver, where the rightness of Jonas' decision to flee his society and thereby to inflict it with memories of otherness and difference is confirmed in Messenger by a reference to the positive transformation of the society which resulted from his action.

\section{REFERENCES}

Beck, Ulrich (1992) Risk Society: Towards a New Modernity. London, Sage.

Beck, Ulrich (1998) Democracy without Enemies. Cambridge, Polity Press. 
Beck, Ulrich, and Elisabeth Beck-Gernsheim (2002) Individualization: Institutionalized Individualism and its Social and Political Consequences. London, Sage.

Boothby, Neil (1996) 'Mobilizing communities to meet the psychosocial needs of children in war and refugee crisis', in R.J. Apfel and B. Simon (eds) Minefields in Their Hearts: The Mental Health of Children in War and Communal Violence. New Haven, Yale University Press, pp.149-164.

Bourdieu, Pierre (1986) 'The forms of capital', trans. Richard Nice, in John G. Richardson (ed) Handbook of Theory and Research for the Sociology of Education. New York, Greenwood.

Burgess, Melvin (1999) Bloodtide. London, Penguin Books.

Castoriadis, Cornelius (1987) The Imaginary Institution of Society, trans Kathleen Blamey. Cambridge, MIT Press.

Ellis, Deborah (2002) Parvana's Journey. Crows Nest, NSW, Allen \& Unwin.

Fukuyama, Francis (1992) The End of History and the Last Man. New York, Free Press.

Fukuyama, Francis (1999) The Great Disruption: Human Nature and the Reconstitution of Social Order. New York, Free Press.

Gaonkar, Dilip Parameshwar (2002) 'Towards new imaginaries: An introduction', Public Culture 14, 1: 1-19.

Gleitzman, Morris (2002) Boy Overboard. Camberwell, Vic., Penguin.

Jacoby, Russell (1999) The End of Utopia: Politics and Culture in the Age of Apathy. New York: Basic Books.

Levey, Jane F. (2001) 'Imagining the family in postwar popular culture: The case of The Egg and I and Cheaper by the Dozen', Journal of Women's History 13, 3: 125-150.
Lowry, Lois (1993) The Giver. Boston, Houghton Mifflin.

Lowry, Lois (2000) Gathering Blue. Boston, Houghton Mifflin.

Lowry, Lois (2004) Messenger. Boston, Houghton Mifflin.

Mark, Jan (2004) Useful Idiots. Oxford, David Fickling Books.

Mikaelsen, Ben (2004) Tree Girl. New York, HarperCollins.

Moylan, Tom (2003) "“The moment is here... and it's important": State, agency, and dystopia in Kim Stanley Robinson's Antarctica and Ursula LeGuin's The Telling', in Raffaella Baccolini and Tom Moylan (eds) Dark Horizons: Science Fiction and the Dystopian Imagination. New York and London, Routledge, pp.135-154.

Nix, Garth (1997) Shade's Children. St Leonards, NSW, Allen \& Unwin.

Pratchett, Terry (1998) Carpe Jugulum. London and New York, Doubleday.

Winter, Ian (2000) Towards a theorised understanding of family life and social capital: Working Paper No. 2, April 2000. Melbourne, Australian Institute of Family Studies.

\section{BIOGRAPHICAL NOTES}

Kerry Mallan is an Associate Professor in the School of Cultural and Language Studies at Queensland University of Technology. Her research interests include children's and young adult literature and film, with particular interests in utopianism, feminist and queer theories, and picture book illustration.

Clare Bradford is Professor of Literary Studies at Deakin University in Melbourne, where she teaches literary studies and children's literature and supervises students undertaking MA and $\mathrm{PhD}$ programmes. Her most recent book is Reading Race: Aboriginality in Australian 
Children's Literature (Melbourne University Press, 2001), which won the Children's Literature Association Book Award and the IRSCL Award. She is the editor of the journal Papers: Explorations into Children's Literature and her forthcoming book, Unsettling Narratives: Postcolonial Readings of Children's Literature, is a comparative study of settler society literatures for children.

John Stephens is professor in English at Macquarie University in Sydney, where he teaches and supervises postgraduate research in children's literature, as well as other literatures. He is the author of Language and Ideology in Children's Fiction; Retelling Stories, Framing Culture (with Robyn McCallum); two books about discourse analysis; and around seventy articles about children's (and other) literature. More recently, he has edited Ways of Being Male: Representing Masculinities in Children's Literature and Film. His current research focus is on the impact on children's literature of global shifts in politics and culture since the end of the Cold War. 